\title{
Single nucleotide polymorphisms for feed efficiency and performance in crossbred beef cattle
}

\author{
Mohammed K Abo-Ismail ${ }^{1,2}$, Gordon Vander Voort ${ }^{1}$, James J Squires ${ }^{1}$, Kendall C Swanson ${ }^{1,3}$, Ira B Mandell ${ }^{1}$, \\ Xiaoping Liao ${ }^{4}$, Paul Stothard ${ }^{4}$, Stephen Moore ${ }^{5}$, Graham Plastow ${ }^{4}$ and Stephen P Miller ${ }^{1,4,5,6^{*}}$
}

\begin{abstract}
Background: This study was conducted to: (1) identify new SNPs for residual feed intake (RFI) and performance traits within candidate genes identified in a genome wide association study (GWAS); (2) estimate the proportion of variation in RFI explained by the detected SNPs; (3) estimate the effects of detected SNPs on carcass traits to avoid undesirable correlated effects on these economically important traits when selecting for feed efficiency; and (4) map the genes to biological mechanisms and pathways. A total number of 339 SNPs corresponding to 180 genes were tested for association with phenotypes using a single locus regression (SLRM) and genotypic model on 726 and 990 crossbred animals for feed efficiency and carcass traits, respectively.

Results: Strong evidence of associations for RFI were located on chromosomes 8, 15, 16, 18, 19, 21, and 28. The strongest association with RFI ( $P=0.0017)$ was found with a newly discovered SNP located on BTA 8 within the ELP3 gene. SNPs rs41820824 and rs41821600 on BTA 16 within the gene HMCN1 were strongly associated with RFI $(P=0.0064$ and $P=0.0033$, respectively). A SNP located on BTA 18 within the ZNF423 gene provided strong evidence for association with RFI ( $P=0.0028$ ). Genomic estimated breeding values (GEBV) from 98 significant SNPs were moderately correlated (0.47) to the estimated breeding values (EBVS) from a mixed animal model. The significant $(P<0.05)$ SNPs (98) explained $26 \%$ of the genetic variance for RFI. In silico functional analysis for the genes suggested 35 and 39 biological processes and pathways, respectively for feed efficiency traits.
\end{abstract}

Conclusions: This study identified several positional and functional candidate genes involved in important biological mechanisms associated with feed efficiency and performance. Significant SNPs should be validated in other populations to establish their potential utilization in genetic improvement programs.

Keywords: Candidate genes, Single nucleotide polymorphism, Feed efficiency, Carcass traits

\section{Background}

As feed costs are a major factor influencing the profitability of beef cattle production, there are many endeavors to reduce these costs. Improving feed efficiency can be achieved by novel feeding strategies and genetic improvement technologies. Although residual feed intake (RFI) has emerged as one of the important feed efficiency traits for beef cattle [1], there are limitations with RFI for direct selection to improve feed efficiency

\footnotetext{
*Correspondence: miller@uoguelph.ca

${ }^{1}$ Centre for Genetic Improvement of Livestock, Department of Animal and Poultry Science, University of Guelph, Guelph, Ontario N1G 2WO, Canada

${ }^{4}$ Livestock Gentec, University of Alberta, Edmonton, AB, Canada

Full list of author information is available at the end of the article
}

industry-wide. These limitations are the expense and difficulty of recording an animal's daily feed intake. Genomic approaches offer opportunities to select cattle that are more efficient, as once the relationships between genetic markers and feed efficiency are determined, this prediction can be applied to animals that are genotyped, but are not phenotyped with costly feed intake measurements [2].

Since 2000, advances in high-throughput genotyping and sequencing techniques have resulted in high density SNP chips, such as the Illumina BovineSNP50 BeadChip [3] being available. The use of the Bovine SNP50 in dairy cattle has increased the accuracy for predicting the

\section{() Biomed Central}


genetic value of animals [4]. In beef cattle, the use of such developments will benefit most traits such as feed efficiency and carcass traits which are difficult to measure or require the animals to be slaughtered for recording their phenotypes [5]. Several genome wide association studies (GWAS) indicated that many genes affect feed efficiency traits and that the majority of these effects are small [6-11]. These studies reported many SNPs conferring genetic variation in feed efficiency. Nonetheless, although many SNPs were studied, the genetic architecture of feed efficiency was not completely explained.

Results from fine-mapping by Abo-Ismail et al. ([12]) suggested a list of candidate genes for further investigation to identify the causal mutations for feed efficiency within these genes [12]. Discovery of the causal mutations within these genes could help explain the genetic architecture of feed efficiency. Furthermore, this approach could provide a panel of the most informative SNPs that could be used to predict feed efficiency accurately and affordably for producers. Therefore, the objectives of this study were to: (1) identify new SNPs for RFI and performance traits within candidate genes identified in previous GWAS studies; (2) estimate the proportion of variation in feed efficiency traits explained by the detected SNPs; (3) estimate the effect of detected SNPs on carcass traits to avoid undesirable correlated effects when selecting for feed efficiency; and (4) map the corresponding genes to a biological process and pathway to understand the biological meaning behind the detected associations. In this way it was hoped to identify causal mutations or to identify markers in strong linkage disequilibrium with such mutations.

\section{Methods}

\section{Animals and phenotypic data}

The study was approved from The University of Guelph Animal Care Committee based on the recommendations outlined in the Canadian Council on Animal Care (1993) guidelines.

\section{Feed efficiency traits}

Average daily dry matter intake (DMI), average daily gain (ADG), midpoint metabolic weight (MMWT), RFI and feed conversion ratio (FCR) phenotypes were measured on 726 crossbred beef cattle, heifers (38), steers (387), and bulls (301) at the University of Guelph's Elora Beef Research Center (EBRC). Average breed compositions were formed by Angus (45.9\%), Simmental (20.7\%), Piedmontese (5\%), Gelbvieh (4.2\%), Charolais (2\%) and Limousin (1.4\%). Animals primarily originated from one of two University of Guelph herds (EBRC and NLARS), the Agriculture and Agri-Food Canada Kapuskasing Research Centre (KAP) or were purchased from producers in Ontario, Canada. Calves were weaned at approximately 200 days of age, and were involved in various post-weaning trials at the EBRC with different nutrition treatments. The body weights of the animals were recorded a number of times over the trials with most trials recording weights at least every four weeks.

The ADG for individual animals was calculated as a linear regression coefficient of their live weights on the actual days of measurement using the nlme package from $\mathrm{R}$ software [13]. The MMBW was calculated as the midpoint body weight $(\mathrm{kg})$ to the power 0.75 . The DMI was calculated for each animal as total DMI divided by number of days for the test period. The RFI was calculated from the difference between the average of the animal's actual daily DMI and its expected daily DMI [14]. Expected DMI was determined through the regression coefficients estimated from the data through a multiple phenotypic regression model as follows:

$$
y_{i j k}=\mu+\beta_{1}\left(A D G_{k}\right)+\beta_{2}\left(M W T_{k}\right)+\operatorname{Sex}_{i}+T_{T Y}+e_{i j k}
$$

Where, $y_{i j k}$ is the total DMI for animal $k$ during the feeding period, $\mu$ is the overall mean, $\beta 1$ is the regression coefficient of the linear regression on ADG as determined through a linear regression of weights on days on trial as described, $\beta 2$ is the regression coefficient of the linear regression on MMWT, $\operatorname{sex}_{i}$ is the effect of $i^{\text {th }}$ sex, TTY $_{j}$ is the effect of $j^{\text {th }}$ treatment $\times$ trial $\times$ year ( 42 levels) and $e_{i j k}$ is the residual random effect associated with the animal $\mathrm{k}$ and is the resulting RFI used in further analyses.

\section{Carcass and meat quality traits}

The association analysis of carcass and meat quality traits was carried out on 693-990 (depending on the trait) crossbred animals, including heifers $(n=33)$, steers $(\mathrm{n}=705)$, and bulls $(\mathrm{n}=252)$. In total 698 of these animals have RFI measures. All cattle were slaughtered at the University of Guelph Meat Science Laboratory Abattoir. Hot carcass weight (HCW) was measured just before the carcass was placed in the cooler. Meat Laboratory staff assessed the longissimus muscle interface (i.e. muscle surface) between the $12^{\text {th }}$ and $13^{\text {th }}$ ribs to obtain the following carcass measurements: subcutaneous fat depths between the $1^{\text {st }}$ and $2^{\text {nd }}, 2^{\text {nd }}$ and $3^{\text {rd }}$, and $3^{\text {rd }}$ and $4^{\text {th }}$ quadrants of longissimus muscle (recorded as F1, F2 and F3, respectively), the grade fat (GRF), the minimum measurement of subcutaneous fat depth within the $4^{\text {th }}$ quadrants of longissimus muscle and longissimus muscle area, measured using an electronic planimeter (MOP-3; Carl Zeiss Inc., Thornwood, NY) after acetate tracing (Bergen et al. [15]). Canadian Beef Grading Agency formulae (www.beefgradingagency.ca/) were used to determine lean yield (LY), an estimate of the percentage 
of the carcass that is red meat. Marbling was assessed to determine the average amount, size and distribution of fat particles or deposits within longissimus muscle andwas scored as $\leq 3.0=$ devoid; 3.1 to $4.0=$ traces; 4.1 to $5.9=$ slight; 6.0 to $7.0=$ small to moderate; and $\geq 7.0=$ slightly abundant to abundant. Rib dissection traits were also measured using a 4-6 rib section depending on the trial and year (physical separation of ribs 8-12 or 6-12, respectively). This procedure determines the amount of lean meat and bone, and a quantitative and qualitative assessment of fat depots (body, subcutaneous and intermuscular) within the rib to evaluate carcass composition. A complete description of carcass measurements was discussed by [15].

\section{SNP discovery, DNA isolation and genotyping}

Messenger RNA from seven tissue types (adipose, muscle, hypothalamus, duodenum, liver, lung and kidney) was extracted using TRIzol (Invitrogen). The tissue samples were collected from beef cattle at the Lacombe Research Centre in Alberta (Canada). RNA from 7 to 14 animals was pooled for each tissue before sequencing. Sequencing libraries were constructed from each RNA pool according to a standard protocol (mRNA Sequencing Sample Preparation Guide, Illumina, USA). Sequencing was performed on the Illumina Genome Analyzer II following the manufacturer's recommendations. The resulting reads (more than $140 \mathrm{M}$ ) were mapped to transcript sequences from the reference bovine genome assembly (Btau4.0) [16] using maq 0.6.6 [17]. More than 1.2 million SNPs were detected by comparing the aligned reads to the reference transcripts. From this list a subset of 300 SNPs from 215 candidate genes was selected based on SNP functional consequences assigned by NGS-SNP [18]. An additional 158 coding SNPs were chosen from publicly available SNPs within the same candidate genes (Additional file 1). These genes were selected based on their proximity (on average distance 116,963 base pair) to significant SNPs identified in a previous study [12].

Tissue or blood samples were prepared and sent to Laboratory Services, University of Guelph, for genomic DNA extraction. Then, prepared DNA samples were sent to GeneSeek, Inc. for genotyping using a commercial platform for high-throughput SNP genotyping. In total, 1,032 animals, as assessed by the numerator relationship matrix using $\mathrm{CFC}$, born subsequent to the animals used in the GWAS population [12] were genotyped for 458 SNP. The 300 SNPs identified through this work that were verified through genotyping have been submitted to dbSNP under the handle name "UALG".

Quality control (QC) was done using the GenABEL package [19] in R software. Animals $(\mathrm{n}=14)$ and individual SNPs $(n=5)$ with a low call-rate $(<90 \%)$ were excluded from the analysis. Mean Identical By State (IBS) was $0.783 \pm 0.0327$. Animals $(n=1)$ with high estimation of IBS $(\geq 0.95)$ were excluded. SNPs $(n=114)$ with a minor allele frequency (MAF) $(<1 \%)$ were excluded from the analysis of feed efficiency traits. Mean autosomal heterozygosity (HET) was $0.27 \pm 0.036$; animals $(\mathrm{n}=6)$ with high HET $(\geq 0.446)$ were excluded. Three hundred thirty nine SNPs and 727 animals passed all QC criteria where these SNPs were mapped to 180 corresponding genes $(83,58,24,9,4$, and 2 genes including only $1,2,3,4,5$ and 6 SNPs, respectively). The distribution of genotyped SNPs (339) across 29 chromosomes of the bovine genome is presented in Figure 1.

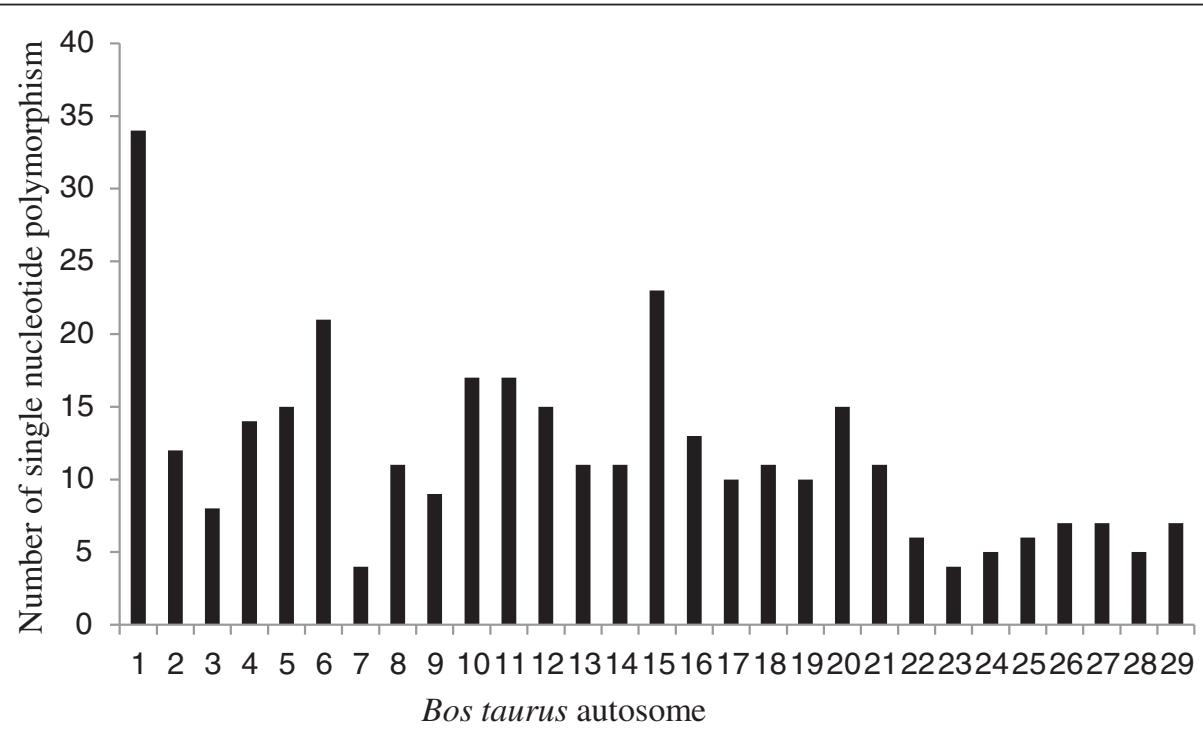

Figure 1 The distribution of 339 genotyped SNP across 29 chromosomes of the bovine genome. 


\section{Association analysis}

\section{Single locus regression model (SLRM)}

Genotypic data were coded as $0,1,2$ corresponding to the number of minor alleles using GenABEL. In this model, phenotypes were regressed on the number of copies of a minor allele $(0,1$, or 2$)$ for estimating the allele's substitution effect using ASReml 3 software [20]. For feed efficiency traits, the univariate animal model was fitted as follows:

$$
\begin{aligned}
\mathrm{Y}_{\mathrm{ijkl}}= & \mu+\operatorname{Sex}_{\mathrm{i}}+\mathrm{HY}_{\mathrm{j}}+\mathrm{TTYk}+\beta_{1} \mathrm{SNP}_{1} \\
& +\beta_{2} \mathrm{AET}_{1}+\sum_{\text {breed }=1}^{1} \beta_{1} \text { breed }+\beta_{9} \mathrm{HET}_{1} \\
& +\mathrm{a}_{1}+\mathrm{e}_{\mathrm{ijkl}}
\end{aligned}
$$

in which $Y_{\mathrm{ijkl}}$ is the trait measured in the $\mathrm{l}^{\text {th }}$ animal of the $\mathrm{j}^{\text {th }}$ herd-year of birth and the $\mathrm{k}^{\text {th }}$ treatment-trial-year group; $\mu$ is the overall mean for the trait; $\operatorname{Sex}_{i}$ is the fixed effect of the $i^{\text {th }}$ sex of $1^{\text {th }}$ animal; $\mathrm{HY}_{j}$ is the fixed effect of the $j^{\text {th }}$ (17 level) herd-year of birth group; $\mathrm{TTY}_{\mathrm{k}}$ is the fixed effect of the $\mathrm{k}^{\text {th }}$ (42 level) treatment trial-year of the test group; $\beta_{1}$ is the regression coefficient of the linear regression on the number of copies of a minor allele; $\beta_{2}$ is the regression coefficient of the linear regression on age at the end of the test period (AET) of the $1^{\text {th }}$ animal; $\beta_{1}$ is the regression coefficient of the linear regressions on proportion of $\mathrm{AN}, \mathrm{CH}, \mathrm{LM}, \mathrm{SM}, \mathrm{PI}$, and GV breeds in the $1^{\text {th }}$ animal; $\beta_{9}$ is the regression coefficient of the linear regression on the percentage of heterozygosity of the $\mathrm{l}^{\text {th }}$ animal; $\mathrm{a}_{1}$ is the random additive genetic (polygenic) effect of the $1^{\text {th }}$ animal; and $\mathrm{e}_{\mathrm{ijklm}}$ is the residual random effect associated with the $1^{\text {th }}$ animal. The TTY level that had less than three animals was excluded from the analysis. Phenotypes that were not within the mean \pm 3 standard deviations for the respective trait were excluded from the analysis.

For carcass traits, the previous model (2) was modified to include the effect of the treatment trial-year-sex group instead of TTY and to include the fixed effect of the herd-year slaughter season instead of HY. Also, the effect of age at the end of the test period (day) was substituted by the age at slaughter (day).

The significance of associations was determined by an overall value of $\mathrm{P}<0.05$. To allow for multiple hypothesis-testing, chromosome wise false discovery rate (FDR) was used [21]. A threshold of 5 and 20\% FDR were used for strong and suggestive associations, respectively.

\section{Genotypic model}

This model was fitted only for feed efficiency traits to consider genetic effects other than the additive effect. The model included the same effects in the SLRM, except that the allele substitution effect was replaced with the genotype effect. This model was not fitted for carcass traits to reduce the volume of results as the trait of primary interest was feed efficiency for this study.

\section{Estimation of genetic variance explained by identified SNPs}

The proportion of phenotypic variance in RFI explained by the full set of SNPs (339) that passed QC was estimated using the BayesC algorithm implemented in GenSel 3.13 software [22]. Also, the proportion of the genetic variance of RFI explained by the set of significant SNPs for at least one of the feed efficiency traits using SLRM and/or the genotypic model was estimated. Missing genotypes were inferred using fastPHASE [23]. Estimated breeding value (EBV) was determined with the SLRM without the regression on SNPs by ASReml. BayesC was then used to run the analysis with the two sets of SNPs (the full set [339 SNPs] and significant SNPs from the two models [98 SNPs]). Posterior residual and genetic variances were estimated after 41,000 iterations including 1,000 burn-in cycles. The proportion of genetic variance explained by the set of SNPs was estimated as the posterior genetic variance divided by phenotypic variance (posterior residual plus posterior genetic variance). In addition, the correlations between genomic breeding values predicted by estimated solutions and EBVs were estimated.

\section{Enrichment analysis}

The significant $(\mathrm{P}<0.05)$ SNPs $(98)$ from the SLRM and genotype models for at least one feed efficiency trait from the association analysis were mapped to 74 genes. The list of the genes was submitted to DAVID 6.7 Beta software [24] for an in silico functional analysis. In DAVID, Gene ontology (GO) was used to identify functionally related genes. The genes were also mapped to biological pathways using web software in the Kyoto Encyclopedia of Genes and Genomes (KEGG) [25].

\section{Results and discussion}

\section{Heritability estimates}

Our goal in the current study was to identify informative or causal mutations for feed efficiency traits for use in Marker Assisted Selection (MAS). This would accelerate genetic improvement in beef cattle by improving the accuracy of selection and shortening intervals between generations [26]. Genetic Improvement of feed efficiency could subsequently minimize methane production [27] while optimizing beef production. In this study, a crossbred population was used to evaluate the relationship between potential genes identified from fine mapping and RFI. The descriptive statistics of feed efficiency, performance and carcass traits are given in Table 1. Using the single trait animal model in ASReml, the estimates 
Table 1 Descriptive statistics (mean, SD, min and max) in feedlot beef cattle for feed efficiency, performance and carcass traits

\begin{tabular}{|c|c|c|c|c|c|}
\hline Trait $^{1}$ & $\mathrm{No}^{2}$ & Mean & SD & Min & $\operatorname{Max}$ \\
\hline \multicolumn{6}{|l|}{ Feed efficiency traits: } \\
\hline Average daily gain (ADG), $\mathrm{kg} \mathrm{d}^{-1}$ & 726 & 1.70 & 0.385 & 0.71 & 3.30 \\
\hline Mid-test metabolic weight (MMWT), kg & 726 & 92.4 & 11.70 & 53.3 & 128.1 \\
\hline Daily dry matter intake (DMI), $\mathrm{kg} \mathrm{d}^{-1}$ & 726 & 9.81 & 1.76 & 4.18 & 15.54 \\
\hline Residual feed intake (RFI), $\mathrm{kg} \mathrm{d}^{-1}$ & 726 & -0.066 & 1.126 & -3.70 & 3.35 \\
\hline Feed conversion ratio (FCR), $\mathrm{kg}_{\text {gain }} \mathrm{kg}^{-1} \mathrm{DM}$ & 726 & 6.09 & 1.87 & 3.11 & 16.76 \\
\hline \multicolumn{6}{|l|}{ Carcass traits: } \\
\hline Hot carcass weight (HCW), kg & 959 & 353.7 & 52.47 & 208 & 503 \\
\hline Longissimus muscle area (LMA), $\mathrm{cm}^{2}$ & 848 & 94.3 & 14.61 & 59.4 & 138.4 \\
\hline Lean meat within the rib section (LR), \% & 664 & 54.6 & 6.79 & 25.0 & 75.2 \\
\hline Lean yield grade (LY), \% & 846 & 60.1 & 2.78 & 51.0 & 65.0 \\
\hline Fat1 (F1), mm & 850 & 13.4 & 5.62 & 1.0 & 30.0 \\
\hline Fat2 (F2), mm & 850 & 15.7 & 6.49 & 1.0 & 36.0 \\
\hline Fat3 (F3), mm & 847 & 9.6 & 3.66 & 1.0 & 22.0 \\
\hline Grade fat (GRF), mm & 846 & 8.8 & 3.25 & 1.0 & 19.0 \\
\hline Proportion of intermuscular fat (IFR) within the rib section, \% & 687 & 10.09 & 3.22 & 1.2 & 20.5 \\
\hline Proportion of body cavity fat within the rib section (BFR), \% & 684 & 3.48 & 1.244 & 0.96 & 7.30 \\
\hline Proportion of subcutaneous fat from the rib section (SQFR), \% & 685 & 10.30 & 2.60 & 2.44 & 18.53 \\
\hline Marbling score ${ }^{b}$ & 851 & 4.90 & 0.734 & 3.0 & 6.0 \\
\hline
\end{tabular}

${ }^{1} \mathrm{~F} 1$, subcutaneous fat depth between the $1^{\text {st }}$ and $2^{\text {nd }}$ quarter of the longissimus; $F 2$, subcutaneous fat depth between $2^{\text {nd }}$ and $3^{\text {rd }}$ quarter of the longissimus; $\mathrm{F} 3$, subcutaneous fat depth between the $3^{\text {rd }}$ and $4^{\text {th }}$ quarter of the longissimus.

${ }^{2}$ No. = Number of animals' phenotypes and genotypes for testing the association.

${ }^{\mathrm{b}}$ Marbling was scored as $\leq 3.0=$ devoid; 3.1 to $4.0=$ traces; 4.1 to $5.9=$ slight; 6.0 to $7.0=$ small to moderate; and $\geq 7.0=$ slightly abundant to abundant.

of heritabilities are given in Table 2. Heritability estimates for feed efficiency traits are in the range reported in the literature. The estimated heritability for RFI (0.19) is within the reported range from 0.16 to $0.45[28,29]$, whereas heritability (0.35) for ADG is in agreement with [30]. Estimated heritability for DMI $(0.42)$ is within the reported range, from 0.31 to 0.44 [30,31]. FCR $(0.25)$ is also within the reported range $(0.17$ to 0.37$)[28,30]$ as is MMWT (0.48) from 0.36 to $0.69[28,29]$. The genetic variation and moderate heritabilities in feed efficiency traits indicate effective selection would be possible, where the trait is measured. However, the detected genetic variation also indicates that MAS could be effective where the genetic markers are closely linked to or is the causative mutation and that have repeatable effects across independent populations.

\section{Association analysis}

In the current study, SNP effects were estimated using an allele substitution effect model or the genotypic model. To avoid population stratification effects from influencing the estimated SNP effect, the phenotypes were adjusted for breed proportion, and the polygenic effect was fitted using the animal model to account for possible family effects [32]. The population used in the
GWAS using the Illumina BovineSNP50 was different animals to those used in the current study. However, the two populations are not independent as the animals in the current study were born subsequent to the animals used in the GWAS population from the same primary herds. The average relatedness among individuals between the two populations was estimated to be low at 0.0005 on average using the numerator relationship matrix calculated using CFC [33]. There was zero pedigree-based inbreeding among the animals used in the current study. There was no separate dataset for feed efficiency traits on the same 339 SNP chip that could be used for validation. Thus, these significant associations require validation in other independent populations.

Results indicated 15 SNPs were significantly (at less $5 \%$ FDR) associated with at least one feed efficiency trait phenotype using the allele substitution effect model (Table 3). These findings reveal several candidate genes that provide highly significant evidence of association with RFI (Table 3). These promising candidate genes are located on Bos taurus autosomes (BTA) 8, 15, 16, 18, 19, 21 , and 28. The strongest evidence of association with RFI and DMI was in SNP (8: 10674426) in the three prime untranslated region (3' UTR) of gene elongation protein 3 homolog (ELP3). Gene ELP3 modulates transcription by 
Table 2 The heritability estimates $\left(h^{2}\right) \pm$ standard error (SE) for growth and feed efficiency related traits estimated in crossbred beef cattle

\begin{tabular}{|c|c|}
\hline Trait $^{1}$ & $h^{2} \pm S E$ \\
\hline Average daily gain, $\mathrm{kg} \mathrm{d}^{-1}$ & $0.35 \pm 0.12$ \\
\hline Mid-test metabolic weight, kg & $0.48 \pm 0.13$ \\
\hline Daily dry matter intake, $\mathrm{kg} \mathrm{d}^{-1}$ & $0.42 \pm 0.17$ \\
\hline Residual feed intake, $\mathrm{kg} \mathrm{d}^{-1}$ & $0.19 \pm 0.11$ \\
\hline Feed conversion ratio, $\mathrm{kg}$ gain $\mathrm{kg}^{-1} \mathrm{DM}$ & $0.25 \pm 0.13$ \\
\hline Hot carcass weight $(\mathrm{HCW}), \mathrm{kg}$ & $0.29 \pm 0.10$ \\
\hline Longissimus muscle area (LMA), $\mathrm{cm}^{2}$ & $0.50 \pm 0.11$ \\
\hline Lean meat within the rib section (LR), \% & $0.48 \pm 0.13$ \\
\hline Lean yield grade (LY), \% & $0.31 \pm 0.10$ \\
\hline Fat1 $(F 1), \mathrm{mm}$ & $0.10 \pm 0.08$ \\
\hline Fat2 (F2), mm & $0.24 \pm 0.10$ \\
\hline Fat3 (F3), mm & $0.22 \pm 0.10$ \\
\hline Grade fat (GRF), mm & $0.24 \pm 0.10$ \\
\hline $\begin{array}{l}\text { Proportion of intermuscular fat } \\
\text { (IFR) within the rib section, } \%\end{array}$ & $0.54 \pm 0.14$ \\
\hline $\begin{array}{l}\text { Proportion of body cavity fat within } \\
\text { the rib section (BFR), } \%\end{array}$ & $0.23 \pm 0.12$ \\
\hline $\begin{array}{l}\text { Proportion of subcutaneous fat from } \\
\text { the rib section (SQFR), } \%\end{array}$ & $0.20 \pm 0.12$ \\
\hline Marbling score, & $0.41 \pm 0.10$ \\
\hline
\end{tabular}

${ }^{1} \mathrm{~F} 1$, subcutaneous fat depth between the $1^{\text {st }}$ and $2^{\text {nd }}$ quarter of the longissimus; F2, subcutaneous fat depth between $2^{\text {nd }}$ and $3^{\text {rd }}$ quarter of the longissimus; F3, subcutaneous fat depth between the $3^{\text {rd }}$ and $4^{\text {th }}$ quarter of the longissimus.

${ }^{\mathrm{b}}$ Marbling was scored as $\leq 3.0=$ devoid; 3.1 to $4.0=$ traces; 4.1 to $5.9=$ slight; 6.0 to $7.0=$ small to moderate; and $\geq 7.0=$ slightly abundant to abundant.

working as a catalytic histone acetyltransferase subunit of the RNA polymerase II elongator complex involved in transcriptional elongation $[34,35]$. In Drosophila, reduction in ELP3 expression during the development of the nervous system increases activity and decreases sleep [36] and the growth of adult flies (or could be lethal for the pupa) [37].

In the current study on BTA 16, the splice site intronic mutation (rs41820824) and the missense mutation (rs41821600) within gene hemicentin 1(HMCN1) were associated with RFI, where the substitution with the minor allele was associated with increased RFI and decreased F1. In addition, the minor allele of SNP rs41824268, within gene $H M C N 1$, was associated with decreasing HCW, whereas in SNP rs41820800, it was associated with decreasing F2. Gene HMCN1 is known to be involved in age-related, macular degeneration [38], and polymorphisms within gene HMCN1 were associated with diabetes in man [39].

Synonymous coding SNP (18: 17150858), within the gene encoding zinc finger protein 423 (ZNF423), was associated with RFI, DMI and MMWT and located near a reported QTL (ID: 4449) for DMI [6]. In addition, the minor allele of SNP (18: 17152044) was associated with decreasing GRF, F3, and F2, and increased LY, and was located near a reported QTL (ID: 11062) for LMA and body weight (ID: 11061) [40]. Gene ZNF423 is a transcription factor involved in metal ion-binding. Down regulation of ZNF423 expression increases cell growth and retards differentiation as a consequence of its important role with the Vitamin A metabolite, retinoic acid [41].

On BTA 6, the SNP (6: 37288379) at 3' UTR, within gene protein phosphatase, $\mathrm{Mg}^{2+/} \mathrm{Mn}^{2+}$ dependent, $1 \mathrm{~K}$ $(P P M 1 K)$, was associated with increased MMWT and HCW and decreased RFI, FCR, marbling, and IFR and was located near a reported QTL (ID: 10761) for fat thickness at the $12^{\text {th }}$ rib and a QTL (ID: 10758) for marbling score (EBV) [40] and a QTL (ID: 1753) for milk fat percentage [42]. Gene PPM1K is involved in the phosphorus metabolic process or in amino acid dephosphorylation. In addition, $P P M 1 K$ plays a key role in cellular survival and development by regulating mitochondrial permeability transition pore function [43]. However, different genes are involved in mitochondrial adenosine triphosphate (ATP) synthesis efficiency and associated with differences in RFI [44-46], therefore, the effect of gene PPM1K on mitochondrial ATP synthesis is not clear [43].

For ADG, the most significant (at less than 5\% FDR; $\mathrm{P}=0.0009$ ) SNP (rs41574929) was located on BTA 6, at 5' UTR, within gene family with sequence similarity 190, member (A FAM190A; ID: 616908) (Table 3). The SNP rs41574929 was also associated ssignificantly at less than 5\% FDR with HCW $(\mathrm{P}=0.006)$. This result is in agreement with the function described for FAM190A where it is a necessary regulator for normal mitosis [47]. A deletion mutation in FAM190A causes a cell division defect [47].

Allele substitution effect estimates of SNPs influencing $(\mathrm{P} \leq 0.05)$ growth and efficiency traits, but which did not pass chromosome wise false discovery rate (FDR) threshold $q=0.2$ were listed in Additional file 2. Also, all the SNPs associated at $P$-value $<0.05$ using the genotypic model for growth and feed efficiency traits were listed in Additional file 3.

The association analysis using SLRM indicated that 59 SNPs were strongly (Table 4) or suggestively (Additional file 4) associated at $5 \%$ or $20 \%$ FDR test, respectively, for at least one carcass trait phenotype. Results indicated that the majority of the strong or suggestive associations were for intermuscular fat \% (IFR) (14 indications). Thirteen SNPs were strongly associated with marbling, whereas 12 SNPs were associated with longissimus muscle area (LMA), and as follows HCW (9), F3 (8), GRF (8), F2 (6), LY (6), body cavity fat within the rib section (BFR) (5), \% lean meat within the rib section (LR) 
Table 3 Significant and suggestive SNP based on false discovery rate (FDR) q threshold of 0.05 and 0.2 for feed efficiency traits using single locus regression model (SLRM) on 339 SNPs

\begin{tabular}{|c|c|c|c|c|c|c|c|c|c|}
\hline Trait $^{1}$ & Gene ID ${ }^{2}$ & BTA $^{3}$ & Ref. SNP ${ }^{4}$ & Pos. $(b p)^{5}$ & $\mathrm{MAF}^{6}$ & Alleles $^{7}$ & $n^{8}$ & Estimate $\pm \mathrm{SE}^{9}$ & $P$-value \\
\hline$A D G$ & 523789 & 3 & rs42417924 & 75523597 & 0.102 & $C / G$ & 726 & $-0.062 \pm 0.02$ & $0.0104 \&$ \\
\hline DMl & 616055 & 5 & ss914082855 & 119551668 & 0.37 & $\mathrm{~A} / \mathrm{G}$ & 726 & $-0.234 \pm 0.08$ & $0.0025^{*}$ \\
\hline $\mathrm{DMl}$ & 616055 & 5 & ss914082856 & 119557146 & 0.37 & $\mathrm{~T} / \mathrm{C}$ & 720 & $-0.237 \pm 0.08$ & $0.0023^{*}$ \\
\hline MMWT & 616908 & 6 & rs41574929 & 36099801 & 0.388 & $T / G$ & 716 & $0.992 \pm 0.40$ & $0.0132 \&$ \\
\hline ADG & 616908 & 6 & rs41574929 & 36099801 & 0.388 & $\mathrm{~T} / \mathrm{G}$ & 716 & $0.049 \pm 0.01$ & $0.0009^{*}$ \\
\hline MMWT & 540329 & 6 & ss914082878 & 37288379 & 0.152 & $\mathrm{~T} / \mathrm{C}$ & 726 & $1.342 \pm 0.54$ & $0.0128 \&$ \\
\hline MMWT & 536203 & 6 & ss914082880 & 37386084 & 0.16 & $\mathrm{~A} / \mathrm{G}$ & 725 & $1.293 \pm 0.53$ & $0.0148 \&$ \\
\hline MMWT & 530393 & 6 & rs43702346 & 37439120 & 0.272 & $T / G$ & 723 & $1.421 \pm 0.43$ & $0.0009^{*}$ \\
\hline DMl & 784720 & 8 & ss914082889 & 10674426 & 0.041 & $\mathrm{~A} / \mathrm{G}$ & 726 & $0.620 \pm 0.18$ & $0.0006^{*}$ \\
\hline RFI & 784720 & 8 & ss914082889 & 10674426 & 0.041 & $\mathrm{~A} / \mathrm{G}$ & 726 & $0.483 \pm 0.15$ & $0.0017^{*}$ \\
\hline MMWT & 282689 & 10 & ss914082689 & 50256553 & 0.197 & $\mathrm{~T} / \mathrm{C}$ & 725 & $-1.210 \pm 0.48$ & $0.01 \&$ \\
\hline MMWT & 282689 & 10 & ss914082690 & 50259055 & 0.046 & $A / G$ & 726 & $2.184 \pm 0.89$ & $0.015 \&$ \\
\hline MMWT & 614507 & 10 & ss914082694 & 79315960 & 0.364 & $\mathrm{~T} / \mathrm{C}$ & 718 & $0.933 \pm 0.39$ & $0.0176 \&$ \\
\hline RFI & 533166 & 15 & rs41755948 & 30710940 & 0.207 & $\mathrm{~T} / \mathrm{C}$ & 726 & $-0.201 \pm 0.07$ & $0.007 \&$ \\
\hline RFI & 533166 & 15 & ss914082737 & 30717928 & 0.207 & $\mathrm{~T} / \mathrm{C}$ & 726 & $-0.201 \pm 0.07$ & $0.007 \&$ \\
\hline RFI & 521326 & 16 & rs41821600 & 64875340 & 0.037 & $\mathrm{~A} / \mathrm{T}$ & 726 & $0.496 \pm 0.17$ & $0.0033^{*}$ \\
\hline RFI & 521326 & 16 & rs41820824 & 64950387 & 0.012 & $\mathrm{~A} / \mathrm{G}$ & 726 & $0.785 \pm 0.29$ & $0.0064^{*}$ \\
\hline RFI & 508025 & 18 & ss914082760 & 17150858 & 0.365 & $\mathrm{~T} / \mathrm{C}$ & 723 & $0.191 \pm 0.06$ & $0.0028^{*}$ \\
\hline FCR & 282411 & 19 & rs41914675 & 37278418 & 0.072 & $A / G$ & 726 & $0.278 \pm 0.10$ & $0.004 \&$ \\
\hline RFI & 282411 & 19 & rs41914675 & 37278418 & 0.072 & $\mathrm{~A} / \mathrm{G}$ & 726 & $0.342 \pm 0.12$ & $0.004 \&$ \\
\hline DMl & 282411 & 19 & rs41914675 & 37278418 & 0.072 & $A / G$ & 726 & $0.462 \pm 0.14$ & $0.0008^{*}$ \\
\hline RFI & 524684 & 21 & rs43020736 & 29054823 & 0.371 & $\mathrm{~T} / \mathrm{C}$ & 726 & $-0.162 \pm 0.07$ & $0.016 \&$ \\
\hline DMl & 524684 & 21 & rs43020736 & 29054823 & 0.371 & $\mathrm{~T} / \mathrm{C}$ & 726 & $-0.248 \pm 0.08$ & $0.0018^{*}$ \\
\hline RFI & 524684 & 21 & rs43020769 & 29060759 & 0.478 & $\mathrm{~A} / \mathrm{G}$ & 726 & $0.172 \pm 0.07$ & $0.009 \&$ \\
\hline MMWT & 532512 & 25 & ss914082815 & 36278405 & 0.11 & $\mathrm{~T} / \mathrm{C}$ & 719 & $1.555 \pm 0.63$ & $0.014 \&$ \\
\hline MMWT & 532512 & 25 & ss914082816 & 36279504 & 0.02 & $\mathrm{~T} / \mathrm{C}$ & 726 & $3.099 \pm 1.31$ & $0.018 \&$ \\
\hline MMWT & 515895 & 27 & ss914082827 & 39798548 & 0.08 & $\mathrm{~A} / \mathrm{G}$ & 726 & $-2.298 \pm 0.71$ & $0.0013^{*}$ \\
\hline DMl & 508697 & 28 & ss914082834 & 7727734 & 0.426 & $\mathrm{~A} / \mathrm{G}$ & 726 & $-0.211 \pm 0.08$ & $0.0067^{*}$ \\
\hline RFI & 508697 & 28 & ss914082834 & 7727734 & 0.426 & $\mathrm{~A} / \mathrm{G}$ & 726 & $-0.183 \pm 0.07$ & $0.005^{*}$ \\
\hline RFI & 780878 & 28 & ss914082829 & 13580673 & 0.187 & $\mathrm{~T} / \mathrm{A}$ & 726 & $-0.208 \pm 0.08$ & $0.009^{*}$ \\
\hline
\end{tabular}

'average daily gain (ADG), $\mathrm{kg} \mathrm{d}^{-1}$, average daily dry matter intake (DMI), $\mathrm{kg} \mathrm{d}^{-1}$, mid-point metabolic weight (MMWT), $\mathrm{kg}^{75}$, feed efficiency conversion ratio (FCR), $\mathrm{kg}_{\text {gainkg- }}{ }^{1} \mathrm{DM}$ and residual feed intake (RFI) $\mathrm{kg} \mathrm{d}^{-1}$.

"is a significant SNP after adjusting for chromosome-wise $5 \%$ false discovery rate.

$\&$ is a suggestive SNP after adjusting for chromosome-wise $20 \%$ false discovery rate.

Gene $I D^{2}=$ Entrez gene identifier.

$\mathrm{BTA}^{3}=$ Bos taurus autosome.

Ref. $\mathrm{SNP}^{4}=(\mathrm{rs} \#)$ is a reference SNP ID number and (ss\#) ID is the National Center for Biotechnology Information (NCBI) assay ID number assigned by NCBI to submitted SNPs for discovered SNPs using RNA-Seq.

Pos. $(b p)^{5}=$ the SNP's position in a base pair.

$\mathrm{MAF}^{6}=$ minor allele frequency.

Alleles ${ }^{7}=$ first allele/second allele, the second allele is the minor allele which the phenotypes regressed on its number $(0,1$, and 2$)$.

$\mathrm{n}^{8}=$ Number of animals' phenotypes and genotypes for testing the association.

Estimate $\pm \mathrm{SE}^{9}=$ allele substitution effect \pm standard error.

(4), \% subcutaneous fat within the rib section (SQFR) (4), and F1 (2).

Significant effects (at less 5\% FDR) were found in 27 genes where gene ERCC5 (ID: 509602) had the highest proportion of the effects, revealing 8 of the significant associations with carcass traits (Table 4). The newly discovered SNP on BTA 12 (76889667 bp), within gene ERCC5 (ID: 509602), provided evidence of association with 5 of the studied carcass traits where the substitution of the minor allele was associated with increases of 
Table 4 Significant SNP based on false discovery rate (FDR) $q$ threshold of 0.05 for beef carcass traits using single locus regression model

\begin{tabular}{|c|c|c|c|c|c|c|c|c|}
\hline Trait $^{1}$ & Gene ID ${ }^{2}$ & BTA $^{3}$ & Ref. SNP ${ }^{4}$ & BPPos $^{5}$ & $\mathrm{MAF}^{6}$ & $\mathrm{n}^{7}$ & Estimate $\pm \mathrm{SE}^{8}$ & $P$-value ${ }^{*}$ \\
\hline$L R$ & 539020 & 1 & rs43246339 & 81372644 & 0.165 & 664 & $1.151 \pm 0.266$ & 0.00002 \\
\hline IFR & 539020 & 1 & rs43246339 & 81372644 & 0.167 & 687 & $-0.622 \pm 0.172$ & 0.0003 \\
\hline IFR & 614882 & 2 & rs43287969 & 1280728 & 0.329 & 648 & $0.404 \pm 0.143$ & 0.005 \\
\hline F3 & 532545 & 2 & rs43307594 & 43392336 & 0.379 & 847 & $0.473 \pm 0.15$ & 0.0016 \\
\hline IFR & 538378 & 2 & rs42315485 & 58475918 & 0.035 & 687 & $-0.968 \pm 0.355$ & 0.0065 \\
\hline Marbling & 522946 & 3 & ss914082840 & 2555332 & 0.445 & 851 & $-0.097 \pm 0.028$ & 0.00066 \\
\hline Marbling & 522946 & 3 & ss914082841 & 2557106 & 0.379 & 837 & $-0.092 \pm 0.031$ & 0.003 \\
\hline LMA & 532836 & 4 & rs41599809 & 96565402 & 0.107 & 848 & $3.08 \pm 0.975$ & 0.0016 \\
\hline LMA & 532836 & 4 & ss914082853 & 96570062 & 0.37 & 848 & $-1.807 \pm 0.617$ & 0.0035 \\
\hline Marbling & 538086 & 5 & ss914082862 & 50301829 & 0.414 & 851 & $-0.091 \pm 0.03$ & 0.0025 \\
\hline IFR & 503621 & 6 & ss914082876 & 32016672 & 0.131 & 687 & $0.625 \pm 0.191$ & 0.001 \\
\hline $\mathrm{HCW}$ & 616908 & 6 & rs41574929 & 36099801 & 0.397 & 949 & $5.277 \pm 1.916$ & 0.006 \\
\hline Marbling & 540329 & 6 & ss914082878 & 37288379 & 0.166 & 851 & $-0.117 \pm 0.038$ & 0.002 \\
\hline IFR & 540329 & 6 & ss914082878 & 37288379 & 0.14 & 687 & $-0.535 \pm 0.178$ & 0.0028 \\
\hline $\mathrm{HCW}$ & 540329 & 6 & ss914082878 & 37288379 & 0.162 & 959 & $7.16 \pm 2.468$ & 0.0038 \\
\hline Marbling & 536203 & 6 & ss914082880 & 37386084 & 0.174 & 850 & $-0.121 \pm 0.037$ & 0.001 \\
\hline IFR & 536203 & 6 & ss914082880 & 37386084 & 0.152 & 685 & $-0.511 \pm 0.172$ & 0.003 \\
\hline HCW & 530393 & 6 & rs29010894 & 37433382 & 0.124 & 958 & $-7.542 \pm 2.706$ & 0.005 \\
\hline IFR & 530393 & 6 & rs43702346 & 37439120 & 0.276 & 684 & $-0.393 \pm 0.14$ & 0.005 \\
\hline SQF & 616568 & 7 & ss914082884 & 10135670 & 0.129 & 928 & $-0.022 \pm 0.008$ & 0.004 \\
\hline GRF & 616568 & 7 & ss914082884 & 10135670 & 0.13 & 819 & $-0.572 \pm 0.206$ & 0.0056 \\
\hline Fat3 & 541122 & 9 & rs43013785 & 33837458 & 0.487 & 841 & $0.431 \pm 0.148$ & 0.004 \\
\hline IFR & 529759 & 11 & ss914082698 & 80982741 & 0.066 & 687 & $0.928 \pm 0.28$ & 0.00097 \\
\hline Marbling & 537649 & 12 & ss914082709 & 13011713 & 0.294 & 851 & $0.125 \pm 0.033$ & 0.0002 \\
\hline F3 & 537649 & 12 & ss914082709 & 13011713 & 0.293 & 847 & $0.443 \pm 0.171$ & 0.0097 \\
\hline IFR & 535653 & 12 & rs43694364 & 15748029 & 0.483 & 687 & $0.379 \pm 0.131$ & 0.0039 \\
\hline GRF & 509602 & 12 & ss914082715 & 76885563 & 0.411 & 845 & $0.409 \pm 0.137$ & 0.0029 \\
\hline LR & 509602 & 12 & ss914082715 & 76885563 & 0.425 & 663 & $-0.584 \pm 0.201$ & 0.0037 \\
\hline F3 & 509602 & 12 & ss914082715 & 76885563 & 0.411 & 846 & $0.431 \pm 0.15$ & 0.004 \\
\hline IFR & 509602 & 12 & ss914082716 & 76889667 & 0.413 & 686 & $-0.503 \pm 0.135$ & 0.0002 \\
\hline LYR & 509602 & 12 & ss914082716 & 76889667 & 0.413 & 663 & $0.748 \pm 0.208$ & 0.0003 \\
\hline SQFR & 509602 & 12 & ss914082716 & 76889667 & 0.414 & 684 & $-0.355 \pm 0.119$ & 0.003 \\
\hline F3 & 509602 & 12 & ss914082716 & 76889667 & 0.417 & 846 & $-0.439 \pm 0.153$ & 0.004 \\
\hline GRF & 509602 & 12 & ss914082716 & 76889667 & 0.418 & 845 & $-0.381 \pm 0.14$ & 0.0065 \\
\hline F3 & 512287 & 15 & ss914082741 & 4101726 & 0.099 & 843 & $0.865 \pm 0.254$ & 0.00068 \\
\hline Fat1 & 521326 & 16 & rs41821600 & 64875340 & 0.038 & 849 & $-2.099 \pm 0.627$ & 0.00085 \\
\hline Marbling & 540672 & 20 & rs43006895 & 54577104 & 0.479 & 851 & $0.1 \pm 0.029$ & 0.0006 \\
\hline F2 & 540672 & 20 & rs43006895 & 54577104 & 0.478 & 850 & $0.904 \pm 0.287$ & 0.0017 \\
\hline BFR & 534312 & 21 & rs41980260 & 33909131 & 0.282 & 683 & $-0.162 \pm 0.057$ & 0.0049 \\
\hline BFR & 534312 & 21 & rs41980261 & 33909583 & 0.282 & 684 & $-0.151 \pm 0.057$ & 0.008 \\
\hline LMA & 512725 & 23 & ss914082809 & 32192762 & 0.488 & 848 & $1.609 \pm 0.611$ & 0.0086 \\
\hline LMA & 512725 & 23 & ss914082812 & 32207295 & 0.283 & 848 & $1.84 \pm 0.703$ & 0.009 \\
\hline LMA & 504741 & 24 & rs42047790 & 36412358 & 0.445 & 848 & $2.087 \pm 0.625$ & 0.0009 \\
\hline
\end{tabular}




\begin{tabular}{|c|c|c|c|c|c|c|c|c|}
\hline LMA & 540050 & 26 & rs42106947 & 37495213 & 0.488 & 848 & $-1.766 \pm 0.611$ & 0.004 \\
\hline BFR & 518905 & 27 & ss914082824 & 39712547 & 0.015 & 684 & $0.714 \pm 0.231$ & 0.002 \\
\hline IFR & 515895 & 27 & ss914082827 & 39798548 & 0.076 & 687 & $0.654 \pm 0.237$ & 0.006 \\
\hline SQFR & 515895 & 27 & ss914082827 & 39798548 & 0.077 & 685 & $0.569 \pm 0.208$ & 0.006 \\
\hline
\end{tabular}

${ }^{1} \mathrm{~F} 1$, subcutaneous fat depth between the $1^{\text {st }}$ and $2^{\text {nd }}$ quarter of the longissimus; F2, subcutaneous fat depth between $2^{\text {nd }}$ and $3^{\text {rd }}$ quarter of the longissimus; F3, subcutaneous fat depth between the $3^{\text {rd }}$ and $4^{\text {th }}$ quarter of the longissimus; Marbling was scored as $\leq 3.0=$ devoid; 3.1 to $4.0=$ traces; 4.1 to $5.9=$ slight; 6.0 to $7.0=$ small to moderate; and $\geq 7.0=$ slightly abundant to abundant; HCW = Hot carcass weight $(\mathrm{kg}) ; \mathrm{LMA}=$ longissimus dorsi muscle area (cm2); LR = lean meat within the rib section (\%); LY = Lean yield grade (\%); GRF = Grade fat (mm); IFR = Intermuscular fat (\%); BFR=Body cavity fat within the rib section (\%); SQFR $=$ Proportion of subcutaneous fat from the rib section (\%); ${ }^{*}$ is a significant SNP after adjusting for chromosome-wise $5 \%$ false discovery rate. Gene ID $I^{2}=$ Entrez gene identifier; BTA B $^{3}$ Bos taurus autosome; Ref. SNP $=(r s \#)$ is a reference SNP ID number and (ss\#) ID is the National Center for Biotechnology Information (NCBI) assay ID number assigned by NCBI to submitted SNPs for discovered SNPs using RNA-Seq.

BPPos $^{5}=$ the SNP's position in a base pair; $M F^{6}=$ minor allele frequency; $n^{7}=$ Number of animals' phenotypes and genotypes for testing the association; Estimate $\pm \mathrm{SE}^{8}=$ allele substitution effect \pm standard error, the minor allele which the phenotypes regressed on its number $(0,1$, and 2$)$.

LYR and decreases in marbling, F3, GRF, IFR and SQFR (Table 4). Another newly discovered SNP in gene ERCC5 (76885563 bp) was strongly associated with three carcass traits where the substitution of the minor allele was associated with increases in F3, and GRF and decreases in LR (Table 4). Gene ERCC5 is involved in response to abiotic stimulus and negative regulation of programmed cell death and nucleotide excision repair pathway. In mice selected for high muscle mass, ERCC5 was located in QTL for lean mass [48].

SNP on BTA 27 (39712547 bp), within gene solute carrier family 20 (phosphate transporter), member 2 (SLC20A2; ID: 518905), was associated with one carcass trait where the substitution of the minor allele was associated with an increase in BFR (Table 4). The SLC20A2 is involved in ion and cation transport. In human, mutations within SLC20A2 are associated with idiopathic basal ganglia calcification [49].

SNP rs43702346 on BTA 6, within gene polycystic kidney disease 2 (PKD2; ID: 530393), was significantly associated with two carcass traits where substitution with the minor allele was associated with a decrease in HCW and IFR (Table 4). The PKD2 gene is involved in negative regulation of G1/S transition of mitotic cell cycle process. Gene PKD2 is near an identified QTL for bone percentage, fat percentage, meat percentage, meat-tobone ratio, moisture content and subcutaneous fat [50]. In human, polymorphisms within PKD2 may take part in the development of gout [51].

\section{The in silico functional analysis}

In the current study, the 74 genes containing significant $(\mathrm{P}<0.05)$ SNPs were submitted to DAVID for enrichment analysis. In total 39 genes out of the 74 genes were enriched in 35 biological process terms (Table 5). Ion transport and cation transport mechanisms contained the highest number of genes associated with feed efficiency traits. In addition, some genes affecting feed efficiency traits in the current study were involved in proteolysis, protein complex biogenesis, and protein amino acid glycosylation. The ion transport mechanism in conjunction with protein turnover and metabolism account for $37 \%$ of the variation in RFI [52].

In ruminants protein synthesis accounts for 23\% of total energy use in the whole body[53] and protein turnover accounts for $42 \%$ of total gastrointestinal tract energy use [54]. In the current study, some genes were involved in phosphorus metabolic processes, phosphorylation, and amino acid phosphorylation. Protein metabolism can be controlled by changing the phosphorylation status [55]. Genes involved in phosphorus metabolic processes and phosphorylation mechanisms regulate the metabolism of energy [56]. In the current study, regulation of transcription mechanisms contributed to variation in feed efficiency traits. The connection between a functional mutation in a specific transcription factor can increase or decrease expression of genes involved in glucose, amino acid, lipid, and cholesterol metabolism [57]. Other studies have demonstrated that genes that up-regulate in response to nutritional restriction are involved in transcription control [58].

The in silico functional study of genes having significant SNPs revealed potential pathways likely to contribute to variation in feed efficiency traits (Table 6). Mitogenactivated protein kinases (MAPK) signaling pathway included three of the identified genes (RASA1, CACNA1G and $S T K 3)$. In a study of the differences in global gene expression between high and low RFI animals, the majority of up-regulated genes in low RFI animals were stimulated by MAPKs [59], where the MAPKs were involved in signal transduction pathways to activate different cellular processes, such as cell division, differentiation, and cell death as a response to hormones and stress [60]. The TYR gene is involved in Riboflavin metabolism, melanogenesis, tyrosine metabolism, and catecholamine biosynthesis, and the minor allele of SNP rs42402428, within gene TYR (ID: 280951) was associated with decreasing FCR. Polymorphisms in gene TYR have been associated with 
Table 5 Enriched biological processes for 39 genes holding significant SNPs $(P$-value $<0.05)$ for feed efficiency traits

\begin{tabular}{|c|c|c|c|}
\hline Biological process & No & P value $^{\ddagger}$ & Genes \\
\hline Ion transport & 8 & 0.006 & $618639,518905,281701,530393,540113,510792,282411,614299$ \\
\hline Cation transport & 7 & 0.004 & $618639,518905,530393,540113,510792,282411,614299$ \\
\hline Phosphorus metabolic process & 7 & 0.057 & $504429,533815,540329,540113,100048947,281848,512125$ \\
\hline Phosphorylation & 6 & 0.072 & $504429,533815,540113,100048947,281848,512125$ \\
\hline Metal ion transport & 5 & 0.034 & $618639,518905,530393,282411,614299$ \\
\hline Regulation of transcription & 5 & 0.762 & $517336,509259,529124,540474,784720$ \\
\hline Protein amino acid phosphorylation & 5 & 0.126 & $504429,533815,100048947,281848,512125$ \\
\hline Monovalent inorganic cation transport & 4 & 0.060 & $618639,518905,540113,614299$ \\
\hline Regulation of transcription, DNA-dependent & 4 & 0.722 & $517336,529124,540474,784720$ \\
\hline Transmembrane transport & 4 & 0.236 & $512725,281701,540113,282411$ \\
\hline Proteolysis & 3 & 0.756 & $617222,524684,534774$ \\
\hline Intracellular signalling cascade & 3 & 0.643 & $530393,614507,281848$ \\
\hline Regulation of transcription from RNA polymerase II promoter & 3 & 0.290 & $517336,540474,784720$ \\
\hline Transcription & 3 & 0.636 & $509259,529124,784720$ \\
\hline RNA processing & 3 & 0.320 & $100048947,512925,281712$ \\
\hline Potassium ion transport & 2 & 0.359 & 618639,614299 \\
\hline $\begin{array}{l}\text { Nucleobase, nucleoside, nucleotide } \\
\text { and nucleic acid biosynthetic process }\end{array}$ & 2 & 0.497 & 540113,510792 \\
\hline Calcium ion transport & 2 & 0.279 & 530393,282411 \\
\hline Regulation of homeostatic process & 2 & 0.152 & 530393,282411 \\
\hline Response to abiotic stimulus & 2 & 0.448 & 509602,530393 \\
\hline Negative regulation of programmed cell death & 2 & 0.476 & 509602,282032 \\
\hline Protein complex biogenesis & 2 & 0.545 & 509259,281848 \\
\hline Determination of symmetry & 2 & 0.067 & 497208,530393 \\
\hline Microtubule-based process & 2 & 0.441 & 497208,512287 \\
\hline Blood vessel morphogenesis & 2 & 0.351 & 282689,282032 \\
\hline Protein transport & 2 & 0.833 & 282044,614507 \\
\hline Protein amino acid autophosphorylation & 2 & 0.130 & 281848,512125 \\
\hline Neurological system process & 2 & 0.679 & 281701,538198 \\
\hline Oxidation reduction & 2 & 0.899 & 280951,532512 \\
\hline mNRA metabolic process & 2 & 0.495 & 100048947,281712 \\
\hline Cell-cell adhesion & 1 & 1.000 & 540672 \\
\hline Protein amino acid glycosylation & 1 & 1.000 & 532545 \\
\hline Muscle cell development & 1 & 1.000 & 529759 \\
\hline Amino acid transport & 1 & 1.000 & 511955 \\
\hline
\end{tabular}

${ }^{\ddagger} \mathrm{P}$ value of the enriched biological process for genes' list having significant SNP.

changing the coat colour of Braunvieh cattle [38]. Gene GALNT13, affecting ADG, MMWT, DMI, F2, GRF, HCW, LMA, LY, and F3, is involved in mucin type O-Glycan biosynthesis. Gene ATP6V1E2 (ID: 540113), which affects DMI and MMWT, plays an important role in various pathways and biological mechanisms. Gene ATP6V1E2 is near an identified QTL for mycobacterium avium spp. Paratuberculosis resistance in Holstein cattle [61]. Gene GTF2F2 (ID: 509259) affected RFI and is involved in basal transcription factors pathways, which regulate glucose, amino acids and protein, lipid metabolism and many other important metabolic processes. Changes in the function of GTF2F2 would be associated with feed efficiency or metabolic diseases [57]. The minor allele of a newly discovered SNP (6: 37386084), within gene ABCG2 (ID: 536203), was associated with decreasing IFR and marbling. The in silico functional analysis showed that gene $A B C G 2$ is involved in ATP-binding cassette $(\mathrm{ABC})$ transporters and bile 
Table 6 The pathways for $\mathbf{1 4}$ genes containing significant SNPs for one feed efficiency trait

\begin{tabular}{|c|c|}
\hline Pathway & Genes \\
\hline bta04010: MAPK signalling pathway & 282032 (RASA1), 282411 (CACNA1G), 533815 (STK3) \\
\hline bta01100: Metabolic pathways & 280951 (TYR), 532545 (GALNT13), 540113 (ATP6V1E2) \\
\hline bta04930: Type II diabetes mellitus & 282411 (CACNA1G), 538996 (ABCC8) \\
\hline bta04145: Phagosome & 512287 (LOC512287), 540113 (ATP6V1E2) \\
\hline bta02010: ABC transporters & 536203 (ABCG2), 538996 (ABCC8) \\
\hline bta04976: Bile secretion & 536203 (ABCG2) \\
\hline bta03013: RNA transport & 616055 (CHADL) \\
\hline bta03022: Basal transcription factors & 509259 (GTF2F2) \\
\hline bta04962: Vasopressin-regulated water reabsorption & 512287 (LOC512287) \\
\hline bta05132: Salmonella infection & 512287 (LOC512287) \\
\hline bta04514: Cell adhesion molecules (CAMs) & $529759($ SDC 1$)$ \\
\hline bta04512: ECM-receptor interaction & 529759 (SDC1) \\
\hline bta05144: Malaria & $529759($ SDC1) \\
\hline bta04966: Collecting duct acid secretion & 540113 (ATP6V1E2) \\
\hline bta04721: Synaptic vesicle cycle & 540113 (ATP6V1E2) \\
\hline bta00190: Oxidative phosphorylation & 540113 (ATP6V1E2) \\
\hline bta05323: Rheumatoid arthritis & 540113 (ATP6V1E2) \\
\hline bta03420: Nucleotide excision repair & 509602 (ERCC5) \\
\hline bta04510: Focal adhesion & 281848 (IGF1R) \\
\hline bta04114: Oocyte meiosis, bta05214: Glioma & 281848 (IGF1R) \\
\hline bta05218: Melanoma, bta05200: Pathways in cancer & 281848 (IGF1R) \\
\hline bta04914: Progesterone-mediated oocyte maturation & 281848 (IGF1R) \\
\hline bta04520: Adherens junction & 281848 (IGF1R) \\
\hline bta04730: Long-term depression, & 281848 (IGF1R) \\
\hline bta04144: Endocytosis & 281848 (IGF1R) \\
\hline bta00740: Riboflavin metabolism & 280951 (TYR) \\
\hline bta04916: Melanogenesis & 280951 (TYR) \\
\hline bta00350: Tyrosine metabolism & 280951 (TYR) \\
\hline bta03015: mRNA surveillance pathway & 281712 (CPSF3) \\
\hline bta03008: Ribosome biogenesis in eukaryotes & 508697 (HEATR1) \\
\hline bta05010: Alzheimer's disease & 534774 (BACE2) \\
\hline bta04360: Axon guidance & 282032 (RASA1) \\
\hline bta04740: Olfactory transduction & 281701 (CNGA3) \\
\hline bta00512: Mucin type O-Glycan biosynthesis & 532545 (GALNT13) \\
\hline bta05164: Influenza A & 100048947 (RNASEL) \\
\hline bta05160: Hepatitis C & 100048947 RNASEL \\
\hline bta04020: Calcium signalling pathway & 282411 (CACNA1G) \\
\hline
\end{tabular}

secretion pathways. The results of gene $A B C G 2$ in the current study agree with reported gene $A B C G 2$ as QTL for increasing milk yield and decreasing milk fat and protein [62-64]. The analysis also indicated that insulin-like growth factor 1 receptor gene IGF1R (ID: 281848) affecting ADG and marbling is involved in seven different pathways. Nonetheless, there was no association between production traits and the genotypes of IGF-IR/TaqI polymorphism [65-67]. This might be because a small number of animals was used to test the association in those analyses. Functional analysis allows a better understanding of the underlying mechanisms contributing to the genetic variation in feed efficiency, and it sheds light on potential pathways to target in future investigations. 


\section{Genetic variation in RFI explained by candidate genes}

The accuracy of a DNA panel to predict a trait like feed efficiency depends on the amount of genetic variation explained. The 98 SNP set associated $(\mathrm{P}<0.05)$ with at least one feed efficiency trait included SNPs that did not pass the FDR threshold, although they significantly contributed towards building the prediction equation in GWAS. The 98 SNP set explained 26\% of the genetic variance in RFI whereas the proportion explained by the set of 339 SNPs was 29.6\%. The correlation between EBVs of RFI using ASReml and GEBV were 0.52 and 0.66 from the 98 and 399 SNP sets, respectively. Based on the proportion of the genetic variance explained by the 98 SNPs (26\%), the corresponding Beef Improvement Federation (BIF) accuracy is 0.127. Nonetheless, the estimated genetic variance by the 98 SNPs might be overestimated as the additive polygenic animal effect was not included in the model. To improve the accuracy of the SNP panel developed from a crossbred population, a large number of phenotypes is required $(\sim 2000$ animals) [68]. This might partially explain the relatively low estimated accuracy in the current study. In addition, large numbers of identified genes (83 out of 180) from fine mapping RFI were genotyped for only one SNP, and that decreases the probability of detecting the functional mutations. Nonetheless, combining validated SNPs from further fine mapping and the identified 98 SNPs may help develop a DNA test panel for commercial use.

\section{Conclusion}

This study reported SNPs that are significantly associated with RFI, performance, and carcass traits. We postulated that the identified significant SNPs, genes, biological mechanisms and pathways could be the direct cause of the variations in feed efficiency traits and carcass traits. The ability of the significant SNP to predict the genetic merit of feed efficiency and carcass traits should be measured in another population.

\section{Additional files}

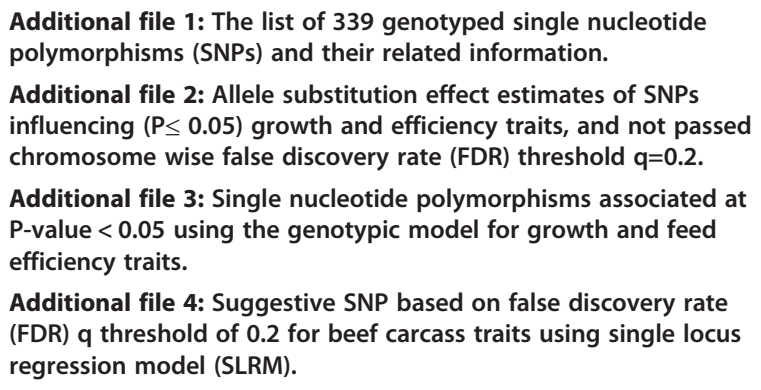

\section{Abbreviations}

SNP: Single nucleotide polymorphism; QTL: Quantitative trait loci; FDR: False discovery rate; BTA: Bos taurus autosome; RFI: Residual feed intake;
ADG: Average daily gain; DMI: Average daily dry matter intake, MMWT, Mid-point metabolic weight; FCR: Feed efficiency conversion ratio (kg gain $\left.\mathrm{kg}^{-1} \mathrm{DM}\right) ; \mathrm{F1}$ : Subcutaneous fat depth between the 1st and 2nd quarter of the longissimus; F2: Subcutaneous fat depth between 2nd and 3rd quarter of the longissimus; F3: Subcutaneous fat depth between the 3rd and 4th quarter of the longissimus; HCW: Hot carcass weight (kg); LMA: Longissimus dorsi muscle area (cm2); LR: Lean meat within the rib section (\%); LY: Lean yield grade (\%); GRF: Grade fat (mm); IFR: Intermuscular fat (\%); BFR: Body cavity fat within the rib section (\%); SQFR: Proportion of subcutaneous fat from the rib section (\%); EBRC: Elora Beef Research Center; KAP: the Agriculture and Agri-Food Canada Kapuskasing Research Centre; NLARS: New Liskeard Agriculture Research Station.

\section{Competing interests}

The authors declare that they have no competing interests.

\section{Authors' contributions}

MKA contributed in designing the study, preparing the phenotypes and genotypes, performing the statistical and enrichment analysis, and drafting the manuscript. RV performed the data editing and statistical analysis. GV and IBM provided help in collection of data, analysis and manuscript editing. EJS and KCS participated in designing the study, collection of data and manuscript editing. PS, SM, GP participated in designing the study, preparing the genotypes, and editing the manuscript. SPM helped in design, data collection, analysis, and draft the manuscript. All authors' read and approved the final manuscript.

\section{Acknowledgement}

The authors wish to thank: The staff at the Elora Beef Research Centre and the University of Guelph Meat Science laboratory and Tim Caldwell for their assistance with data collection and analysis. Financial support was provided by: Ontario Cattlemen's Association, Agriculture Adaptation Council (FIP), Agriculture and Agri-food Canada (Growing Forward), Canadian Cattlemen's Beef Cattle Research Council, Ontario Ministry of Agriculture Food and Rural Affairs, Alberta Beef Producers and Alberta Livestock and Meat Agency.

\section{Author details}

${ }^{1}$ Centre for Genetic Improvement of Livestock, Department of Animal and Poultry Science, University of Guelph, Guelph, Ontario N1G 2W0, Canada. ${ }^{2}$ Department of Animal and Poultry Science, Damanhour University, Damanhour, Egypt. ${ }^{3}$ Animal Sciences Department, North Dakota State University, Fargo, ND, USA. ${ }^{4}$ Livestock Gentec, University of Alberta, Edmonton, $A B$, Canada. ${ }^{5}$ Queensland Alliance Agr \& Food Innovation, University of Queensland, St Lucia, Qld 4072, Australia. ${ }^{6}$ Animal and Poultry Science Department, Ontario Agriculture College, University of Guelph, 50 Stone Road, Guelph, ON N1G 2W1, Canada.

Received: 4 September 2013 Accepted: 27 January 2014 Published: 30 January 2014

\section{References}

1. Wulfhorst JD, Ahola JK, Kane SL, Keenan LD, Hill RA: Factors affecting beef cattle producer perspectives on feed efficiency. J Anim Sci 2010, 88(11):3749-3758.

2. Meuwissen TH, Hayes BJ, Goddard ME: Prediction of total genetic value using genome-wide dense marker maps. Genetics 2001, 157(4):1819-1829.

3. Matukumalli LK, Lawley CT, Schnabel RD, Taylor JF, Allan MF, Heaton MP, O'Connell J, Moore SS, Smith TP, Sonstegard TS, et al: Development and characterization of a high density SNP genotyping assay for cattle. PLoS One 2009, 4(4):e5350.

4. Hayes BJ, Bowman PJ, Chamberlain AJ, Goddard ME: Invited review: genomic selection in dairy cattle: progress and challenges. J Dairy Sci 2009, 92(2):433-443.

5. Dekkers JC, Hospital F: The use of molecular genetics in the improvement of agricultural populations. Nat Rev Genet 2002, 3(1):22-32.

6. Nkrumah JD, Sherman EL, Li C, Marques E, Crews DH Jr, Bartusiak R, Murdoch B, Wang Z, Basarab JA, Moore SS: Primary genome scan to identify putative quantitative trait loci for feedlot growth rate, feed intake, and feed efficiency of beef cattle. J Anim Sci 2007, 85(12):3170-3181. 
7. Barendse W, Reverter A, Bunch RJ, Harrison BE, Barris W, Thomas MB: A validated whole-genome association study of efficient food conversion in cattle. Genetics 2007, 176(3):1893-1905.

8. Sherman EL, Nkrumah JD, Moore SS: Whole genome single nucleotide polymorphism associations with feed intake and feed efficiency in beef cattle. J Anim Sci 2010, 88(1):16-22.

9. Bolormaa S, Hayes BJ, Savin K, Hawken R, Barendse W, Arthur PF, Herd RM, Goddard ME: Genome-wide association studies for feedlot and growth traits in cattle. J Anim Sci 2011, 89(6):1684-1697.

10. Mujibi FD, Nkrumah JD, Durunna ON, Grant JR, Mah J, Wang Z, Basarab J, Plastow G, Crews DH Jr, Moore SS: Associations of marker panel scores with feed intake and efficiency traits in beef cattle using preselected single nucleotide polymorphisms. J Anim Sci 2011, 89(11):3362-3371.

11. Snelling WM, Allan MF, Keele JW, Kuehn LA, Thallman RM, Bennett GL, Ferrell CL, Jenkins TG, Freetly HC, Nielsen MK, et al: Partial-genome evaluation of postweaning feed intake and efficiency of crossbred beef cattle. J Anim Sci 2011, 89(6):1731-1741.

12. Abo-Ismail MK, Squires EJ, Swanson KC, Lu D, Wang Z, Mah J, Plastow G, Moore SS, Miller SP: Fine mapping QTL and candidate genes discovery for residual feed intake on Chromosomes 5, 15, 16, and 19 in beef cattle. In Proceedings of the 9th World Congress on Genetics Applied to Livestock Production: 1-6 August 2010; Leipzig. Edited by German Society for Animal Science; 2010:0783.

13. Pinheiro J, Bates D, DebRoy S, Sarkar D, Team. tRDC: nlme: Linear and Nonlinear Mixed Effects Models. R package version 3.1-102. 2011

14. Arthur PF, Renand G, Krauss D: Genetic and phenotypic relationships among different measures of growth and feed efficiency in young Charolais bulls. Livest Prod Sci 2001, 68(2):131-139.

15. Bergen R, Miller SP, Mandell IB, Robertson WM: Use of live ultrasound, weight and linear measurements to predict carcass composition of young beef bulls. Can J Anim Sci 2005, 85(1):23-35.

16. Sequencing TBG, Consortium A, Elsik CG, Tellam RL, Worley KC: The genome sequence of taurine cattle: a window to ruminant biology and evolution. Science 2009, 324(5926):522-528.

17. Li H, Ruan J, Durbin R: Mapping short DNA sequencing reads and calling variants using mapping quality scores. Genome Res 2008, 18(11):1851-1858.

18. Grant JR, Arantes AS, Liao X, Stothard P: In-depth annotation of SNPs arising from resequencing projects using NGS-SNP. Bioinformatics 2011, 27(16):2300-2301

19. Aulchenko YS, Ripke S, Isaacs A, van Duijn CM: GenABEL: an R library for genome-wide association analysis. Bioinformatics (Oxford, England) 2007, 23(10):1294-1296.

20. Gilmour AR, Gogel BJ, Cullis BR, Welham SJ, Thompson R: ASReml User Guide Release 3.0. Hemel Hempstead, HP1 1ES, UK: VSN International Ltd; 2009.

21. Benjamini $Y$, Hochberg $Y$ : Controlling the false discovery rate: a practical and powerful approach to multiple testing. J R Stat Soc Ser B Methodol 1995, 57(1):289-300.

22. Fernando RL, Garrick D: GenSel-User manual for a portfolio of genomic Selection related analyses. 2009 [http://taurus.ansci.iastate.edu]

23. Scheet $P$, Stephens M: A fast and flexible statistical model for large-scale population genotype data: applications to inferring missing genotypes and haplotypic phase. Am J Hum Genet 2006, 78(4):629-644.

24. da Huang W, Sherman BT, Lempicki RA: Systematic and integrative analysis of large gene lists using DAVID bioinformatics resources. Nat Protoc 2009, 4(1):44-57.

25. Kanehisa M, Goto S, Furumichi M, Tanabe M, Hirakawa M: KEGG for representation and analysis of molecular networks involving diseases and drugs. Nucleic Acids Res 2010, 38(Database issue):D355-D360.

26. Davis GP, DeNise SK: The impact of genetic markers on selection. J Anim Sci 1998, 76(9):2331-2339.

27. Nkrumah JD, Okine EK, Mathison GW, Schmid K, Li C, Basarab JA, Price MA, Wang Z, Moore SS: Relationships of feedlot feed efficiency, performance, and feeding behavior with metabolic rate, methane production, and energy partitioning in beef cattle. J Anim Sci 2006, 84(1):145-153.

28. Herd RM, Bishop SC: Genetic variation in residual feed intake and its association with other production traits in British Hereford cattle. Livest Prod Sci 2000, 63(2):111-119.

29. Crowley JJ, McGee M, Kenny DA, Crews DH Jr, Evans RD, Berry DP. Phenotypic and genetic parameters for different measures of feed efficiency in different breeds of Irish performance-tested beef bulls. J Anim Sci 2010, 88(3):885-894.
30. Schenkel FS, Miller SP, Wilton JW: Genetic parameters and breed differences for feed efficiency, growth, and body composition traits of young beef bulls. Can J Anim Sci 2004, 84(2):177-185.

31. Arthur PF, Archer JA, Johnston DJ, Herd RM, Richardson EC, Parnell PF: Genetic and phenotypic variance and covariance components for feed intake, feed efficiency, and other postweaning traits in Angus cattle. J Anim Sci 2001, 79(11):2805-2811.

32. Goddard ME, Hayes BJ: Mapping genes for complex traits in domestic animals and their use in breeding programmes. Nat Rev Genet 2009, 10(6):381-391.

33. Sargolzaei $M$, Iwaisaki $H$, Colleau JJ: CFC: A tool for monitoring genetic diversity. In The 8th World Congress on Genetics Applied to Livestock Production: Aug. 13-18, 2006; Belo Horizonte, Brazil. Edited by Instituto Prociência; 2006:27-28

34. Wittschieben $B O$, Otero $G$, de Bizemont $T$, Fellows J, Erdjument-Bromage $H$, Ohba R, Li Y, Allis CD, Tempst P, Svejstrup JQ: A novel histone acetyltransferase is an integral subunit of elongating RNA polymerase II holoenzyme. Mol Cell 1999, 4(1):123-128.

35. Karam CS, Kellner WA, Takenaka N, Clemmons AW, Corces VG: 14-3-3 mediates histone cross-talk during transcription elongation in Drosophila. PLoS Genet 2010, 6(6):e1000975.

36. Singh N, Lorbeck MT, Zervos A, Zimmerman J, Elefant F: The histone acetyltransferase Elp3 plays in active role in the control of synaptic bouton expansion and sleep in Drosophila. J Neurochem 2010, 115(2):493-504.

37. Walker J, Kwon SY, Badenhorst P, East P, McNeill H, Svejstrup JQ: Role of elongator subunit Elp3 in Drosophila melanogaster larval development and immunity. Genetics 2011, 187(4):1067-1075.

38. Schmutz SM, Berryere TG, Ciobanu DC, Mileham AJ, Schmidtz BH, Fredholm $\mathrm{M}$ : A form of albinism in cattle is caused by a tyrosinase frameshift mutation. Mamm Genome 2004, 15(1):62-67.

39. Kim S, Abboud HE, Pahl MV, Tayek J, Snyder S, Tamkin J, Alcorn H Jr, Ipp E, Nast CC, Elston RC, et al: Examination of association with candidate genes for diabetic nephropathy in a Mexican American population. Clin J Am Soc Nephrol 2010, 5(6):1072-1078.

40. McClure MC, Morsci NS, Schnabel RD, Kim JW, Yao P, Rolf MM, McKay SD, Gregg SJ, Chapple RH, Northcutt SL, et al: A genome scan for quantitative trait loci influencing carcass, post-natal growth and reproductive traits in commercial Angus cattle. Anim Genet 2010, 41(6):597-607.

41. Huang S, Laoukili J, Epping MT, Koster J, Holzel M, Westerman BA, Nijkamp W, Hata A, Asgharzadeh S, Seeger RC, et al: ZNF423 is critically required for retinoic acid-induced differentiation and is a marker of neuroblastoma outcome. Cancer Cell 2009, 15(4):328-340.

42. Ashwell MS, Heyen DW, Sonstegard TS, Van Tassell CP, Da Y, VanRaden PM, Ron M, Weller Jl, Lewin HA: Detection of quantitative trait loci affecting milk production, health, and reproductive traits in Holstein cattle. J Dairy Sci 2004, 87(2):468-475.

43. Lu G, Ren S, Korge P, Choi J, Dong Y, Weiss J, Koehler C, Chen J-n, Wang Y: A novel mitochondrial matrix serine/threonine protein phosphatase regulates the mitochondria permeability transition pore and is essential for cellular survival and development. Genes Dev 2007, 21(7):784-796.

44. Kelly AK, Waters SM, McGee M, Fonseca RG, Carberry C, Kenny DA: mRNA expression of genes regulating oxidative phosphorylation in the muscle of beef cattle divergently ranked on residual feed intake. Physiol Genomics 2011, 43(1):12-23.

45. Kelly DP, Scarpulla RC: Transcriptional regulatory circuits controlling mitochondrial biogenesis and function. Genes Dev 2004, 18(4):357-368.

46. Kolath WH, Kerley MS, Golden JW, Keisler DH: The relationship between mitochondrial function and residual feed intake in Angus steers. J Anim Sci 2006, 84(4):861-865.

47. Patel K, Scrimieri F, Ghosh S, Zhong J, Kim M-S, Ren YR, Morgan RA, lacobuzio-Donahue CA, Pandey A, Kern SE: FAM190A deficiency creates a cell division defect. Am J Pathol 2013, 183(1):296-303.

48. Kärst S, Cheng $R$, Schmitt AO, Yang H, de Villena FPM, Palmer AA, Brockmann GA: Genetic determinants for intramuscular fat content and water-holding capacity in mice selected for high muscle mass. Mamm Genome 2011, 22(9-10):530-543.

49. Zhang Y, Guo X, Wu A: Association between a Novel Mutation in < italic $>$ SLC20A2</italic > and Familial Idiopathic Basal Ganglia Calcification. PLoS One 2013, 8(2):e57060.

50. Gutiérrez-Gil B, Williams JL, Homer D, Burton D, Haley CS, Wiener P: Search for quantitative trait loci affecting growth and carcass traits in a cross population of beef and dairy cattle. J Anim Sci 2009, 87(1):24-36. 
51. Lee YH, Song GG: Pathway analysis of genome-wide association studies on uric acid concentrations. Hum Immunol 2012, 73(8):805-810.

52. Richardson EC, Herd RM: Biological basis for variation in residual feed intake in beef cattle. 2. Synthesis of results following divergent selection. Aust J Exp Agric 2004, 44(5):431-440.

53. Caton JS, Bauer ML, Hidari H: Metabolic components of energy expenditure in growing beef cattle - review. Asian-Australasian I Animal Sci 2000, 13(5):702-710.

54. Baldwin RL, Sainz RD: Energy partitioning and modeling in animal nutrition. Annu Rev Nutr 1995, 15:191-211.

55. Berndt $T$, Kumar R: Novel mechanisms in the regulation of phosphorus homeostasis. Physiology (Bethesda, Md) 2009, 24:17-25.

56. Brown DR, DeNise SK, McDaniel RG: Mitochondrial respiratory metabolism and performance of cattle. J Anim Sci 1988, 66(6):1347-1354.

57. Desvergne B, Michalik L, Wahli W: Transcriptional Regulation of Metabolism. Physiological Reviews 2006, 86(2):465-514.

58. Byrne KA, Wang YH, Lehnert SA, Harper GS, McWilliam SM, Bruce HL, Reverter A: Gene expression profiling of muscle tissue in Brahman steers during nutritional restriction. J Anim Sci 2005, 83(1):1-12.

59. Chen Y, Gondro C, Quinn K, Herd RM, Parnell PF, Vanselow B: Global gene expression profiling reveals genes expressed differentially in cattle with high and low residual feed intake. Anim Genet 2011, 42(5):475-490.

60. Pearson G, Robinson F, Beers Gibson T, Xu BE, Karandikar M, Berman K, Cobb MH: Mitogen-activated protein (MAP) kinase pathways: regulation and physiological functions. Endocr Rev 2001, 22(2):153-183.

61. Pant SD, Schenkel FS, Verschoor CP, You Q, Kelton DF, Moore SS, Karrow NA: A principal component regression based genome wide analysis approach reveals the presence of a novel QTL on BTA7 for MAP resistance in holstein cattle. Genomics 2010, 95(3):176-182.

62. Cohen-Zinder M, Seroussi E, Larkin DM, Loor JJ, Wind AE-V, Lee J-H, Drackley $J K$, Band MR, Hernandez AG, Shani M, et al: Identification of a missense mutation in the bovine ABCG2 gene with a major effect on the QTL on chromosome 6 affecting milk yield and composition in Holstein cattle. Genome Res 2005, 15(7):936-944.

63. Olsen HG, Nilsen H, Hayes B, Berg PR, Svendsen M, Lien S, Meuwissen T: Genetic support for a quantitative trait nucleotide in the ABCG2 gene affecting milk composition of dairy cattle. BMC Genet 2007, 8:32.

64. Seroussi E: The concordance test emerges as a powerful tool for identifying quantitative trait nucleotides: lessons from BTA6 milk yield QTL. Anim Genet 2009, 40(2):230-234.

65. Akis I, Oztabak K, Gonulalp I, Mengi A, Un C: IGF-1 and IGF-1r gene polymorphisms in East Anatolian Red and South Anatolian Red cattle breeds. Genetika 2010, 46(4):497-501.

66. Curi RA, Krauskopf MM, Hadlich JC, Fortes MRS, Vankan DM, Silva JAIIV, Oliveira HN, Mota MDS, XUhwsbspssa, pid SX, nrm = iso: Candidate SNPs for carcass and meat traits in Nelore animals and in their crosses with Bos taurus. Pesq Agrop Brasileira 2012, 47:294-301.

67. Zhang R, Li X: Association between IGF-IR, m-calpain and UCP-3 gene polymorphisms and growth traits in Nanyang cattle. Mol Biol Rep 2011, 38(3):2179-2184.

68. Goddard ME, Hayes BJ, Meuwissen T: Genomic selection in farm animal species - lessons learnt and future perspectives. In Proceedings of the 9th World Congress on Genetics Applied to Livestock Production: 1-6 August 2010 Leipzig. Edited by German Society for Animal Science; 2010:701.

\section{Submit your next manuscript to BioMed Central and take full advantage of:}

- Convenient online submission

- Thorough peer review

- No space constraints or color figure charges

- Immediate publication on acceptance

- Inclusion in PubMed, CAS, Scopus and Google Scholar

- Research which is freely available for redistribution

Submit your manuscript at www.biomedcentral.com/submit
C Biomed Central 